International Journal of Advanced Academic Research (Social and Management Sciences) | ISSN: 2488-9849 Vol. 6, Issue 10 (October, 2020) | www.ijaar.org

\title{
AIRPORT MARKETING ATTRIBUTES AND PASSENGERS' WORD OF MOUTH COMMUNICATION
}

\author{
Sonari-Otobo, V.F. ${ }^{1}$ and $*$ Ekeke, J.N. $^{2}$ \\ ${ }^{1 \& 2}$ Department of Hospitality Management \& Tourism, Faculty of Management Sciences, \\ University of Port Harcourt, Choba, Rivers State, Nigeria. \\ tobovea@gmail.com, *Author for correspondence Email: john.ekeke@uniport.edu.ng
}

\begin{abstract}
Purpose: The study examined the effect of airport marketing attributes on word of mouth communication at the Sam Mbakwe Airport, Owerri, Imo State, Nigeria.

Design/Methodology: The descriptive survey research had a dataset of 150 domestic passengers found at the Sam Mbakwe Airport, Owerri during the study period in November, 2019. A well structured questionnaire containing 14 items in addition to 4 demographic items was used to elicit data from the respondents. With the help of SPSS, the data gathered was utilised to validate the model developed for the study empirically through statistical tests.
\end{abstract}

Findings: The inferential statistical analysis revealed that airport terminal facilities and airport security and safety had significant effect on passengers' word of mouth communication.

Originality: The recognition of airport terminal facilities and airport security and safety as marketing attributes having effect on passengers' behavioural intentions constitute a novel contribution in the context of Nigerian tourism industry.

Practical Implications: The provision of airport facilities, safety and security measures which are part of the total tourism product could overwhelm governmental budgetary allocations. The appropriate level of government could seek and establish Public-Private Partnership (PPP) arrangement with suitable local and international venture partners with a view to building and maintaining competitive airport infrastructure and security apparatus with the aim of enhancing air passengers' satisfaction which is capable of promoting passengers' word of mouth communication.

Keywords: Airport infrastructural facilities, Airport security and safety, Venture partners, Word of Mouth Communication 


\section{Introduction}

Air transportation is one of the components of the tourism product which is available at both the tourism generating region and tourism destination region. Like other tourism industries, air transportation is service oriented (Adeniran \& Fadare, 2018) and is driven by advanced technological processes and safety measures (Appelbaum \& Fewster, 2003). As a service oriented industry, great emphasis is placed on customer satisfaction as a condition for survival for the civil aviation industry.

The quest for enhancement of customer satisfaction places a demand for managers of airports and airlines to seek and have a better understanding of their respective target markets' perception of the quality of service deliverable by the service providers in the civil aviation industry. This in necessitated by the high level competitiveness, high passenger volumes, forces of globalisation and other changes in the air transportation business that characterise the civil aviation industry (Bezerra \& Gomes, 2015).

Empirical evidence suggest, that service quality is studied in the industry through the prism of two settings: the airport and in flight service settings (Chen \& Chang, 2005). The first setting describes the quality of service rendered by the airport management, while the latter describes the quality of service which the various domestic and foreign airlines render to their passengers who constitute the bulk of their customers.

Within the context of an airport as a physical evidence of air operations, several scholars (such as Adeniran, \& Fadare, 2018; Moon, Yoon, \& Han, 2016) have examined the effect of airport service quality and physical environment on passengers' behavioural intentions. On the other hand, within the context of in flight service, several empirical studies (such as Oluyisola, George-Kayode, \& Ajayi, 2019; Wong \& Musa, 2011) have also studied the effect of service quality on passengers' behavioural responses to airlines' service delivery. For this current study, the research setting is the airport which serves as a physical evidence.

Previous studies had examined the effect of certain airport attributes on passengers' behavioural intentions in various market and behavoural contexts. Few examples include: airport operations efficiency in Nigeria (Barros, Wanke, Nwaogbe \& Azad, 2017; Nwaogbe, Ogwude \& Ibe (2017); service quality and passengers' satisfaction in Nigeria (Adeniran \& Fadare, 2018), airport security and passenger satisfaction in Turkey (Güreş ,Yılmaz, Arslan, Durmuşçelebi, Yüksel, \& Ünsal, 2017), airport security and safety and passenger satisfaction in Kenya (Njoroge \& Iraki, 2017).

To our knowledge, there is no empirical evidence to show how airport terminal facilities and security and safety influence passengers' word of mouth communication in the air transportation market segment of the tourism sector in Nigeria. The focus of this current empirical study is to contributeto knowledge by filling this apparent gap. In the light of the foregoing, the objective of the study was to investigate the effect of airport marketing attributes on passengers' word of mouth communication at the Sam Mbakwe airport, Owerri, South-East, Nigeria. 


\section{Conceptual Review and Research Model}

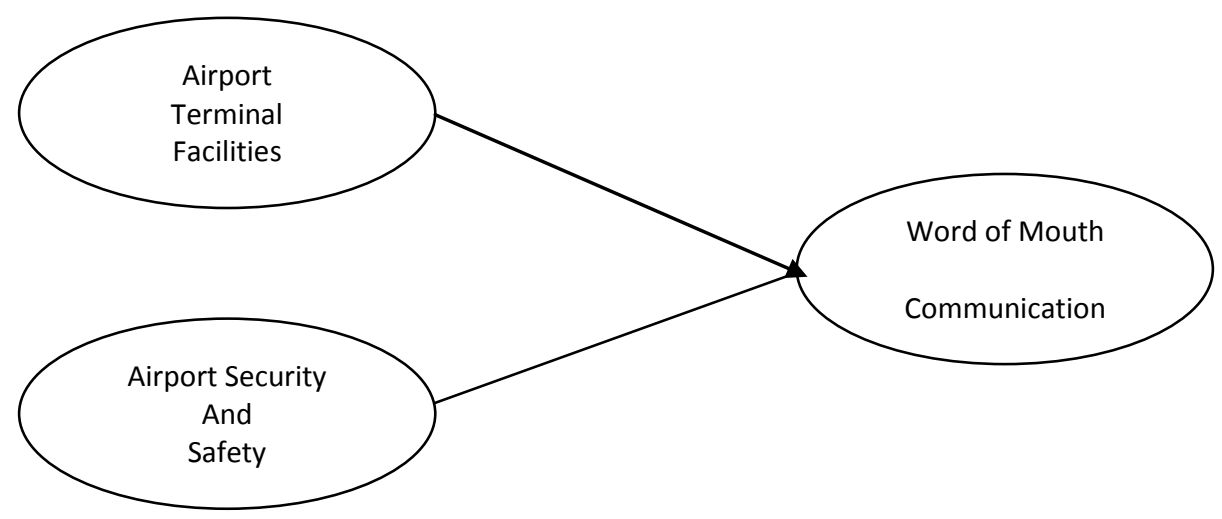

\section{Figure 1: Airport Marketing Attributes and Word of Mouth Communication Model}

The research model demonstrates that airport terminal facilities and airport security and safety are the two dimensions used in investigating the effect of airport marketing attributes on domestic passengers' word of mouth communication at Sam Mbakwe Airport, Owerri.

\section{Airport Marketing Attributes}

Page (2009) recognised transportation as one of the most important components that contribute to the success of the tourism industry at a global scale. Air transportation is one of the segments that make up the transportation system with the airport serving as its takeoff and landing point. In marketing literature, the airport is regarded as the service environment in addition to the airline itself. The target market for air transportation, consist of people in the high echelon of the society, with unique lifestyle and expectations.

Taking cognizance of technology advancements, contemporary air travelers are very demanding in every way imaginable. In addition to the quest for maximum value for their money, both domestic and international air passengers also evaluate airport service attributes and airport environment. The marketing response of airport management in this regard is to seek ways to enhance the service quality level through airport modernization investment and terminal renovations (Bogicevic, Yang, Cobanoglu, Bilgihan, \& Bujisic, 2016). It is on this note, that national governments are engaging in concessionary arrangement as a strategic imperative aimed at enhancing the marketing capabilities of airports. In Nigeria, the Murtala Muhammed International Airport (MMA2), is the only concessioned airport terminal (Adeniran \& Fadare, 2018) in the country.

It is based on the foregoing that, Gee (as cited in Bogicevic, et al., 2016, p.122) noted that a new trend in airport management is to "treat passengers as customers" and to design and develop the airport environment in such a way that its atmosphere offers "a sense of place". This understanding necessitate the concept of airport marketing attributes which defines those airport attributes that are capable of eliciting passengers' emotions and behavioural 
intentions. This current study considers two of such marketing attributes: airport terminal facilities and airport security and safety.

Airport Terminal Facilities: Airport terminal facilities connote the physical environment where a typical airport renders services to its customers. The following facilities are usually provided at an airport: tourist information, car parks, entertainment (shops, including dutyfree, restaurants, cafes, bars), Passenger Information on; land-based travel, waiting rooms, children rooms, rooms for mothers and children, provision for disabled passengers, lost-butfound service, luggage office, medicine service, post service, banks, ATM, etc. At destinations of international repute, airports facilities are designed to cater for a mix of passengers: leisure, business, long haul, and short haul, full cost, low cost, domestic, and international. The needs of the passengers, workers, and visitors are the factors that constrain the design of airport terminals (Edwards, 2005).

Adequate and relevant facilities at an airport will among other things make the waiting time of the passengers at the airport to be very comfortable. The foregoing suggest that, the provision of terminal facilities that are appealing to the passengers is a critical and reasonable and economic objective to be taken seriously by the operators of an airport. Extant literature reveals that the impact of the physical environment on consumers especially in service settings has elicited much attention from scholars (Lin \& Liang, 2011; Bitner, 1990; Ha \& Jang, 2010; Hul, Dube, \& Chebat, 1997; Ryu \& Han, 2011; Baker, 1987; Ryu \& Jang, 2007; Turley \& Milliman, 2000; Wakefield \& Blodgett, 1996), possibly as a result of its effect on passengers' behavioural intentions, customer emotions and positive responses in various facets of tourism and hospitality industry.

Airport Security and Safety: The deadly attacks on the United States of America (USA) of September 11, 2001, raised the consciousness of air travel stakeholders towards airport security and safety. Just like any other business premises, an airport needs the protection of normal security services such as traffic control, crime prevention and fire extinguishments. Edwards (2005) noted that three main ways by which airport maintain security are space syntax, surveillance, and territoriality. Other security and safety measures common with airports include; trained, practiced personnel, proven equipment, well-thought out document procedures, etc.

\section{Positive Word of Mouth (WOM) Communication}

Word of mouth communication connotes "talking about products and services between people apart from companies' advertisement for products or services. These talks can be mutual conversations or unilateral advices and suggestions" (Maisam \& Mahsa, 2016, p.20).As noted by Odor, and Ekeke (2019, p.25) word of mouth has "gained reputation and recognition as a veritable source of communication. It is regarded as a source of information that is free of commercial value to the customer and does not cost the benefiting firm any financial costs". Sen \& Lerman (2007, p.77) defined WOM as "a face-to-face conversation between consumers about a product or service experience". The essential characteristic of WOM is that its source is independent from the benefiting organization and therefore does not have any commercial interest in providing the information or knowledge shared during the interaction. This explains why it is common among family, friends, neighbours and acquaintances (Bansal \& Voyer 2000). It is on the basis of the foregoing that the communication process is considered more credible than firm-generated information (Arndt, as cited in Lo' pez \& Sicilia 2013). 


\section{Empirical Review and Hypotheses Development}

\section{Airport Terminal Facilities and Passengers' Word of Mouth Communication}

At the Jomo Kenyatta International Airport, Kenya, Njoroge and Iraki (2017) investigated the effect of service quality on customer satisfaction. The study used integrated elements of the 22 item SERVQUAL scale developed by Parasuraman et al. (1988) to conduct the quantitative research. The population of interest were 280 departing international travellers found at the airport on the days the questionnaires were administered. The findings show that, atmosphere, state of being safe, ease of way finding, facilities for people with reduced mobility and the availability of leisure rooms, were considered the most significant elements in the passengers' positive experience while at the airport.

In Nigeria, Adeniran and Fadare (2018) utilised SERVQUAL mode to examine passengers' satisfaction and service quality in the domestic terminal of Murtala Muhammed Airport (MMA2), Lagos. The study which sampled 120 domestic passengers through purposeful sampling technique showed that the respondents were only satisfied with only the reliability attribute.

The physical environment of a service brand such as an airport is capable of enhancing the customers' and employees' internal responses such as cognition and emotion as well as external behavioural responses such as brand loyalty and re-patronage. The important issue is that all the measurable physical factors are such that the service firm can control (Bitner, 1990; Moon, et al., 2016). This implies that in the case of an airport, the owners/managers are expected to understand and provide the type of physical environment that is capable of enhancing positive behavioural responses from their customers such as word of mouth communication. We can therefore hypothesize that;

\section{H1: Airport terminal facilities have significant effect on passengers' word of mouth communication in Owerri, Imo State.}

\section{Airport Safety and Security and Passengers' Word of Mouth Communication}

In Turkey, Güreş, et al. (2017) investigated the effect of security practices at airports on European passengers' satisfaction. The results showed a meaningful relationship between the evaluations of the passengers towards security services at the airports and their satisfaction level. Another result showed that evaluations of the passengers towards security services at the airports and their satisfaction level differ according to the flight frequency.

At an international European airport, Ceccato and Masci (2017) studied patterns of passenger's satisfaction with their safety based on a 2014-2015 airline passenger survey on safety. The result showed that passengers were not satisfied with their perceived safety, while they were less satisfied with the following facilities and services: airport entrances, security checkpoints, boarding areas, toilets, and restaurants.

Airport security and safety measures are expected to protect all stakeholders (passengers, airport and airline employees, the public) from hijackings, armed attacks and bombing(Flynn \& Koosatka, 2005). As argued by the Australian Bureau of Transport Safety (ABTS, 2009), organisations operating in the aviation industry are enhancing their competitive advantage through the creation of favaourable brand image in the minds of their various publics and 
customers by portraying themselves as firms that care for their safety. Air passengers will prefer to travel through airports that they perceive to be safe from harm. The fact that security and safety perception of the airport peoples' choices and behaviours (Kinnaird, 1996) makes it a very important attribute that should not be ignored by airport owners and managers.

From the foregoing, we can hypothesize that,

\section{H2: Airport security and safety have significant effect on passengers' word of mouth communication in Owerri, Imo State.}

\section{Research Methodology}

Research design: Descriptive research design was adopted for the empirical study. The survey method is the appropriate design because the research requires collection of data that deal with attitude, preference, behaviour and perception of domestic airline passengers with a focus on the factors that determine word of mouth communication. Also, the research design allows the researcher to hypothesise several variables in measurable relationships.

Sample and data collection: The target population for the study were domestic airline passengers travelling through the Sam Mbakwe Airport Owerri on the days the questionnaires were administered at the airport. The total population was unknown and therefore necessitated the use of Freund and William's formula for sample size determination from unknown population. A sample size of 150 was determined from the process. A wellstructured questionnaire was used to generate data from the respondents. The intercept survey method was used with the advantage of speed and cost effectiveness, while the sampling method adopted was the judgmental sampling technique. Out of a total of 150 questionnaires distributed, 129 were retrieved and they all proved useable and were subjected to data analysis.

\section{Measurement Instrument and Questionnaire design}

The questionnaire was the major instrument for data collection. Extant literature provided the sources of items used. However, in order to conform to the current study's research purpose and context. The two dimensions of airport marketing attributes were measured using items adapted from sources as follows; airport terminal facilities (Adeniran \& Fadare 2018) and airport security and safety (Carr 2001; George, 2003). The four items used for word of mouth communication were adapted from Bansal, and Voyer, (2000).All the measurement items were measured on a five-point Likert-type scale anchored by: Strongly Disagree [SD](1), Disagree [D](2), Agree [A](3), Agree fairly strongly(4) and Strongly Agree [SA](5) to express the degree of agreement with the items or otherwise. 


\section{Research Results}

\section{Reliability Analysis}

Table 1 Reliability Statistics

\begin{tabular}{|r|r|}
\hline \multicolumn{1}{|c|}{$\begin{array}{c}\text { Cronbach's } \\
\text { Alpha }\end{array}$} & N of Items \\
\hline .991 & 14 \\
\hline
\end{tabular}

Table 1 above shows that Cronbach Alpha was used to ascertain the reliability of the 14-item research instrument. The value of the Cronbach Alpha is .991. This value is above the threshold value of .7 suggested by Nunnally and Bernstein (1994). With this result, the internal consistency of the instrument was confirmed and therefore helpful and applicable in measuring opinions of domestic airline passengers towards word of mouth communication in the context of marketing attributes of an airport in Nigeria.

\section{Discriminant Validity}

Table 2 Correlation Matrix

\begin{tabular}{|rr|r|r|r|}
\hline & \multicolumn{1}{|c|}{ ATF } & \multicolumn{1}{c|}{ ASS } & WOM \\
\hline & ATF & 1.000 & & \\
Correlation & ASS & .846 & 1.000 & \\
& WOM & .935 & .897 & 1.000 \\
\hline
\end{tabular}

Table 2 above represents the correlation matrix which is used to determine the discriminant validity of the study instrument. Hair Jr, Black, Babin, and Anderson, (2010, p.126) defined discriminant validity as "the degree to which two conceptually similar concepts are distinct". Fornell and Larker (1981) are of the view that the descriminant validity occurs if the diagonal elements are higher than all the off-diagonal elements in their columns and rows. This requirement is ascertained in Table 2, thus confirming the discriminant validity.

\section{Sampling Adequacy}

Table $3 \mathrm{KMO}$ and Bartlett's Test

\begin{tabular}{|c|r|}
\hline Kaiser-Meyer-Olkin Measure of Sampling Adequacy. & .732 \\
Approx. Chi-Square & 468.033 \\
Bartlett's Test of Sphericity $\quad$ Df & 3 \\
& Sig. \\
\hline
\end{tabular}


Table 3 shows the Exploratory factor analysis performed on 14 exploratory items of airport marketing attributes and passengers' word of mouth communication as specified in the conceptual model in Figure 1 for the conduct of theKMO and Bartlett's Test. Bartlett's test of sphericity is significant at $p v=.000$ and KMO measure of sampling adequacy is .732 which is far greater than 0.5 that has been suggested as a minimum level by Kasser (as cited in Wong \& Musa, 2010, p. 3417).

\section{Data Analyses}

To ascertain the effect of the study dimensions on passengers' word of mouth communication, the hypothesized relationships were subjected to statistical analysis using Multiple regression analysis.

Table 4: Multiple Regression analysis showing the effect of airport terminal facilities and airport security and safety on passengers' word of mouth communication.

Table 4 Model Summary

\begin{tabular}{|l|r|r|r|c|}
\hline Model & $\mathrm{R}$ & $\mathrm{R}$ Square & \multicolumn{1}{|c|}{$\begin{array}{c}\text { Adjusted R } \\
\text { Square }\end{array}$} & $\begin{array}{l}\text { Std. Error of the } \\
\text { Estimate }\end{array}$ \\
\hline 1 & $.956^{\mathrm{a}}$ & .914 & .913 & .28867 \\
\hline
\end{tabular}

a. Predictors: (Constant), Airport Security and Safety, Airport terminal facilities

Table 5 ANOVA A $^{a}$

\begin{tabular}{|c|c|c|c|c|c|c|}
\hline \multicolumn{2}{|c|}{ Model } & Sum of Squares & df & Mean Square & $\mathrm{F}$ & Sig. \\
\hline \multirow{3}{*}{1} & Regression & 111.748 & 2 & 55.874 & 670.491 & $.000^{b}$ \\
\hline & Residual & 10.500 & 126 & .083 & & \\
\hline & Total & 122.248 & 128 & & & \\
\hline
\end{tabular}

a. Dependent Variable: Word of Mouth

b. Predictors: (Constant), Airport Security and Safety, Airport terminal facilities 
Table 6 Coefficients ${ }^{\mathrm{a}}$

\begin{tabular}{|c|c|c|c|c|c|}
\hline \multirow[t]{2}{*}{ Model } & \multicolumn{2}{|c|}{$\begin{array}{c}\text { Unstandardized } \\
\text { Coefficients } \\
\end{array}$} & \multirow{2}{*}{$\begin{array}{c}\text { Standardized } \\
\text { Coefficients }\end{array}$} & \multirow[t]{2}{*}{$\mathrm{T}$} & \multirow[t]{2}{*}{ Sig. } \\
\hline & B & Std. Error & & & \\
\hline (Constant) & -.351 & .082 & & -4.269 & .000 \\
\hline $\begin{array}{l}\text { Airport terminal } \\
\text { facilities }\end{array}$ & .750 & .059 & .618 & 12.640 & .000 \\
\hline $\begin{array}{l}\text { Airport Security and } \\
\text { Safety }\end{array}$ & .398 & .052 & .375 & 7.663 & .000 \\
\hline
\end{tabular}

a. Dependent Variable: Word of Mouth communication

\section{Multiple Regression Analysis}

Tables 5 and 6 show the multiple regression analysis which discloses that un-standardized beta $(\beta)$ of airport terminal facilities and airport security and safety were: $(\beta=0.750)$ and $(\beta=0.398)$ respectively, while value of $\mathrm{R}$ square $=0.914, \mathrm{~F}=670.491 \& p=.000<0.05$. This specifies that airport terminal facilities and airport security and safety explain $91.4 \%$ variation in word of mouth communication by domestic airline passengers in Nigeria.

The result of the regression analysis shows that the two marketing attributes of the airport in influencing airline passengers' behavioural intentions made significant contribution to explaining the dependent variable (see Table 5). The two significant factors are: airport terminal facilities $(\beta$ $=0.750, \mathrm{p}=0.000<0.05)$, airport security and safety $(\beta=0.398, \mathrm{p}=0.000<0.05)$ considering their respective degree of contribution.

This implies that all the variables made significant unique contribution to the equation.

Therefore the model can be written as:

Word of Mouth communication $=0.750(\mathrm{ATF})+.453(\mathrm{ASS})-.350$

The model suggests that by associating any of the two airport marketing attributes with the airport brand, the empirical model can increase the level of word of mouth communication when other things remain constant. Accordingly therefore, changes in airport terminal facilities at the airport can have the biggest influence on level of domestic airline passengers' word of mouth communication as its beta co-efficient $\beta=0.750, p=0.000<0.05$ ); is the highest and significant, followed by airport security and safety, $(\beta=0.398)$. 


\section{Testing of hypotheses 1 and 2}

\section{Decision Rule}

If

$$
\begin{array}{lll}
\mathrm{PV}<0.05 & = & \text { Hypothesis is supported } \\
\mathrm{PV}>0.05 & = & \text { Hypothesis is not supported }
\end{array}
$$

Hypothesis one: The outcome of analysis show that airport terminal facilities had significant effect on passengers' word of mouth communication $(\beta=0.750, p=0.000<0.05)$.

Hypothesis two: The result of analysis show that airport security and safety had significant effect on passengers' word of mouth communication $(\beta=0.465$, $\mathrm{p}=0.000<0.05)$.

The results showed that the two hypotheses were all supported.

\section{Discussion of Results}

The results shown in Table 6, provide support for the two hypotheses (H1 \& H2) conceived for the study. Hypothesis 1 showed a significant effect of airport terminal facilities on passengers' word of mouth communication $(\beta=0.750, p=0.000<0.05)$. Therefore, H1 is supported. This finding is consistent with the findings of Adeniran and Fadare (2018) and Njoroge and Iraki, (2017).

Hypothesis 2 posited a significant effect of airport security and safety on passengers' word of mouth communication. With $(\beta=0.398, p=0.000<0.05)$, the effect is significant. This result is consistent with the prediction of $\mathrm{H} 2$ and is therefore supported. Thus, a higher level of airport security and safety provisions by the airport is associated with a high propensity by airline passengers to recommend the airport to family and friends. This finding is consistent with the finding of Güreş, et al. (2017).

\section{Conclusion and recommendations}

The study investigated the effect of marketing attributes (airport terminal facilities and airport security and safety) on airline passengers' word of mouth communication. Specifically, two hypotheses were postulated. To test the hypotheses, data were collected from airline passengers at Sam Mbakwe airport, Owerri, South East Nigeria. The empirical results supported all the posited research hypotheses significantly.

An important finding of the study is the fact that airport terminal facilities have stronger effects on passengers' word of mouth communication $(0.750)$ than airport security and safety (0.398). Perhaps this could be due to the fact that passengers come in contact with the terminal facilities and make use of them more than they do with security and safety measures which may be hidden from their sight.

In conclusion therefore, the outcome of the research indicates that airport terminal facilities and security and safety measures at an airport constitute important determinants of customers' behavioural intentions, especially passengers' word of mouth communication. It is very important for stakeholders in the aviation industry to provide appropriate terminal facilities and robust security and safety measures at the airport. By and large, the findings of 
this empirical study are expected to have provided purposeful and fruitful implications to both academicians and practitioners.

\section{Study Implications}

On the academic side, this study makes a significant contribution to the tourism marketing attributes of its composite products marketing literature by systematically testing a conceptual model of marketing attributes of an airport and how it affects passengers' behavioural intentions in the Nigerian context. Overall, the current study findings provide tentative support to the proposition that airport terminal facilities and security and safety should be recognized as significant antecedents for gaining and sustaining the airport brand through positive behavioural intentions of the passengers.

On the practitioners' side, the important influence of the marketing attributes of an airport on passengers' behavioural intentions (word of mouth communication) is highlighted. This study therefore argues that marketers can benefit from the implications of these findings. For instance, given the robust relationship between the marketing attributes and passengers' word of mouth communication $\beta=0.750$, and $(\beta=0.398)$ respectively, marketers ought to pay attention to the provision of airport terminal facilities and security and safety measures in such a manner that it will appeal to the passengers. For example, by improving the quality of an airport's terminal facilities, passengers who are the customers are likely to be satisfied and perceive much value in the process. Eventually, the passengers will become attached to a brand that satisfies their needs and they perceive to be trustworthy

However, the provision of airport facilities, safety and security measures which are part of the total tourism product could overwhelm governmental budgetary allocations especially in developing countries like Nigeria. The appropriate level of government could seek and establish Public-Private Partnership (PPP) arrangement with suitable local and international venture partners with a view to building and maintaining competitive airport infrastructure with the aim of enhancing air passengers' perceived value and satisfaction which is capable of promoting passengers' word of mouth communication.

\section{Limitations and Future Research}

The fact that the sample unit for this study was limited to domestic airline passengers at one out of the total number of airports in Nigeria, will definitely make it difficult to generalize the findings. Further research should involve both domestic and foreign airline passengers in all the domestic and international airports in Nigeria.

\section{Acknowledgments}

The authors of this empirical study would like to acknowledge with thanks the following persons;

i. $\quad$ All the domestic airline passengers who participated in this survey.

ii. The management of the Sam Mbakwe Airport at Owerri, Imo State, Nigeria for the permission granted for this study.

iii. The research assistant for helping in the distribution and retrieval of the survey instrument. 


\section{References}

Adeniran, A.O, \& Fadare, S .O (2018) Assessment of Passengers' Satisfaction and Service Quality in Murtala Muhammed Airport (MMA2), Lagos, Nigeria: Application of SERVQUAL Model. Journal of Hotel and Business Management 7(2) 1-2 doi: 10.4172/21690286.1000188

Appelbaum S, \& Fewste,r B. (2003) Global Aviation Human Resource Management: Contemporary Employee and Labour Relations Practices. Management Research News 26: 56-69.

Australian Bureau of Transport Safety (ABTS) Runway Excursions: Part 1- A Worldwide Review of commercial jet Aircraft Runway Excursions. Australian Bureau of Transport Safety, Report No. AR-2008-018.

Baker, J. (1987) "The Role of the Environment in Marketing Services: The consumer perspective". In Czepiel, J., Congram, C.A. \& Shanahan, J. (Eds.), The Services Challenge: Integrating for Competitive Advantage (79-84). Chicago, IL: American Marketing Association.

Bansal, H.S., \&Voyer, P.A., (2000). Word-of-mouth processes within a services purchase decision context. Journal of Service Research 3, (2), 166-

Barros, C. P., Wanke, P., Nwaogbe, O. R. \& Azad, A.K. (2017). Efficiency in Nigerian airports, case studies on transport policy (Science Direct) 5, 573-579. https://doi.org/10.1016/j.cstp.2017.10.003

Bezerra, G. C. L., \& Gomes, C. F. (2015). The effects of service quality dimensions and passenger characteristics on passenger's overall satisfaction with an airport. Journal of Air Transport Management, 44, 77-81. doi:http://dx.doi.org/10.1016/j.jairtraman.2015.03.001

Bitner, M. J. (1990). Evaluating Service Encounters: The Effects of Physical Surroundings and Employee Responses. Journal of Marketing, 54(2), 69-82.

Bitner, M. J., (1992), "Servicescapes: The Impact of Physical Surroundings On Customers and Employees", Journal of Marketing, 56(2): 57-71

Bogicevic, V., Yang, W., Cobanoglu, C., Bilgihan, A., \& Bujisic, M. (2016). Traveler anxiety and enjoyment: The effect of airport environment on traveler's emotions. Journal of Air Transport Management, 57, 122-129. doi:10.1016/j.jairtraman.2016.07.019

Carr, N. (2001). An exploratory study of gendered differences in young tourists perception of danger within London. Tourism Management, 22, 565-570. 
Ceccato, V. \& Masci, S (2017) Airport Environment and Passengers' Satisfaction with Safety. Journal of Applied Security Research, 12:3, 356-373, DOI: $\underline{10.1080 / 19361610.2017 .1315696}$

Chen, F.-Y., \& Chang, Y.-H. (2005). Examining airline service quality from a process perspective. Journal of Air Transport Management, 11(2), 79-87. doi:http://dx.doi.org/10.1016/j.jairtraman.2004.09.002

Edwards, B. (2005). The modern airport terminal. New approaches to airport architecture. Second edition. Oxford: Spoon Press.

Flynn, C \& Kosatka, A. (2005) Civil Aviation in the United States: Security Before and After 9/11. United States: The McGraw-Hill Company.

Fodness, D., \& Murray, B. (2007). Passengers' expectations of airport service quality. Journal of Services Marketing, 21(7), 492-506. doi:doi:10.1108/08876040710824852

Fornell, C., Johnson, M. D., Anderson, E. W., Cha, J., \& Bryant, B. E. (1996). The American customer satisfaction index: Nature, purpose, and findings. Journal of Marketing, 60(4), 7-18.

George, R. (2003). Tourist's perceptions of safety and security while visiting Cape Town. Tourism Management, 24, 575-585

Güreş, N.,Yılmaz, H., Arslan, S., Durmuşcelebi, C Yüksel, C., \& Ünsal, H.H(2017) Researching the Satisfaction Levels of Passengers for Security Services at Airports. International Journal of Marketing Studies; 9, (5), 125-134.

Ha, J. \& Jang, S. (2010), "Perceived Values, Satisfaction and Behavioral Intentions the Role of Familiarity in Korean Restaurants", International Journal of Hospitality Management, Vol. 29 No. 1, pp. 2-13.

Hair, J.F.; Black, W.C.; Babin, B.J.; \&Anderson, R.E. (2010). Multivariate Data Analysis, 7th ed.; Pearson: New York, NY,USA.

Hui, M. K., Dube, L., \& Chebat, J. (1997). The impact of music on consumer's reaction to waiting for services. Journal of Retailing, 73, 87-104.

Kinnaird, V. (1996). Understanding tourism processes: A gender-aware framework. Tourism Management, 17, 2, 95-102.

Lin, J., \& Liang, H. (2011). The influence of service environments on customer emotion and service outcomes. Managing Service Quality, 21(4), $350-372$. 
Lo'pezM., \& Sicilia, M. (2013) How WOM marketing contributes to new product adoption testing competitive communication strategies. European Journal of Marketing 47, (7), 1089-1114.

Maisam, S., \& Mahsa, R. (2016)Positive Word of Mouth Marketing: Explaining the Roles of Value Congruity and Brand Love. Journal of Competitiveness 8 (1), 19 - 37.

Moon, H., Yoon, H. J., \& Han, H. (2016). Role of Airport Physical Environments in the Satisfaction Generation Process: Mediating the Impact of Traveller Emotion. Asia Pacific Journal of Tourism Research, 21(2), 193-211. doi:10.1080/10941665.2015.1048260

Njoroge, S.P., \& X. N. Iraki, X.N (2017). "Service Quality and Customer Satisfaction At Kenyan Airports," Universities, Entrepreneurship and Enterprise Development in Africa, German African University Partnership Platform for the Development of Entrepreneurs and Small/Medium Enterprises.

Nunnally, J. C., \& Bernstein, I. H. (1994).Psychometric theory. 3rd ed. Sydney,Australia McGraw Hill.

Nunnally, J. C., \& Bernstein, I. H. (1994).Psychometric theory. 3rd ed. Sydney,Australia McGraw Hill.

Nwaogbe, O. R., Ogwude, I. C. \& Ibe, C. C. (2017). Efficiency analysis of the Nigeria Airports: An application of DEA-BCC Model. International Scientific Journal of Air Transport Industry (AERO-Journal), 2ed. 28-39. Zinlinska University, Czech Republic.

Odor, C.B. \& Ekeke, J.N (2019). Brand communication and customers' patronage of Port Harcourt Pleasure Park. International Journal of Hospitality, Leisure and Tourism. $3(1 / 2), 22-33$.

Oluyisola, O.O., George-Kayode, B.O. \&\& Ajayi, O.O (2019). Perception of air transport safety by domestic air travelers. International Journal of Hospitality, Leisure and Tourism. 3(1/2), 55-65.

Page, S. (2009). Transport and Tourism: Global Perspectives. Harlow: Pearson Prentice Hall. Ryu, K., \& Jang, S. (2007). The effect of environmental perceptions on behavioral intentions through emotions: The case of upscale restaurants. Journal of Hospitality of Tourism Reseach, 31, 56-72.

Ryu, K., \& Jang, S. (2008). DINESCAPE: A scale for customers"e perception of dining environments. Journal of Foodservice Business Research, 11(1), 2-22.

Ryu, K., \& Han, H. (2011), New or repeat customers: how does physical environment influence their restaurant experience? International Journal of Hospitality Management, 30 (3), 599-611. 
Sen, S., \& Lerman, D. (2007). Why are you telling me this? An examination into negative consumer reviews on the web. Journal of interactive marketing, 21, (4), 76-94.

Turley, L.W. \& Milliman, R.E. (2000), “Atmospheric Effects on Shopping behavior: A review of the experimental evidence", Journal of Business Research, 49, 193-211.

Wakefield, L. K., \& Blodgett, J. G. (1994). The importance of servicescape in leisure service settings. Journal of Service Marketing. 8(3), 66-76.

Wong, K.M \& Musa, G (2011) Branding satisfaction in the Airline Industry: A Comparative Study of Malaysia Airlines and Air Asia. African Journal of Business Management.5(8) 3410-3423. 